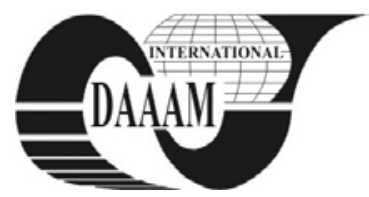

Annals of DAAAM for 2011 \& Proceedings of the 22nd International DAAAM Symposium, Volume 22, No. 1, ISSN 1726-9679 ISBN 978-3-901509-83-4, Editor B. Katalinic, Published by DAAAM International, Vienna, Austria, EU, 2011 Make Harmony between Technology and Nature, and Your Mind will Fly Free as a Bird Annals \& Proceedings of DAAAM International 2011

\title{
CORPORATION FINANCIAL PERFORMANCES AND SUPERVISORY BOARD
}

\author{
KARIC, E[nsad]; SUNJE, A[ziz]; PASIC, M[ugdim] \& BIJELONJA, I[zet]
}

\begin{abstract}
In this paper results of the research of influence of corporation supervisory board characteristics on corporation financial performances are presented. The analysis is done using formal test of hypothesis for the difference between two means of financial performances of corporations with three different supervisory board characteristics using both directional one-tailed and nondirectional two-tailed tests. The level of significance of the statistical tests used in this research is 0,05 . The research sample consists of 101 corporations from Federation of Bosnia and Herzegovina where two-tiered corporate governance model is in use. All observed corporations are listed on Sarajevo Stock Exchange.
\end{abstract}

Key words: supervisory board, financial performance, compensation, optimal board size

\section{INTRODUCTION}

In a nowadays dynamic business environment corporation supervisory boards become crucial factor for the functioning of corporations.

Supervisory boards consists of individuals, who combine their competencies and capabilities that collectively represent the pool of social capital for their corporation and contribute towards executing the governance function (Carpenter \& Westphal, 2001).

Brennan (2006) pointed facts that there is the gap between shareholder and other interested groups expectations vs. supervisory board performance.

Many studies measure supervisory board size by the total number of supervisory board members of a corporation (Bonn, 2004; Coles et al., 2008).

A lot of different studies examined the impact of annual frequency of supervisory board meetings. Supervisory board meetings are part of the decision making process and are considered as an indication of board diligence (Carcello et al., 2002).

Study (Carter, Simkins, and Simpson, 2003) considers supervisory board membership independence as fundamental for the protection of interests of shareholders, advocating that outside members who are independent from the control of management can best represent the shareholder interests.

This research in was based on premises that relationship between corporation financial performances, as dependent variable, and characteristics of supervisory board as independent variables exists. Building of statistical models, like hypothesis tests for the difference between two population means, are used to verify or otherwise disprove the presence of relationships between interacting variables.

Financial performance is measured as ratio between net profit and total sales ratio and is taken as dependent variable. The following three variables are recognized as independent ones: (a) total number of supervisory board members; (b) structure of supervisory board in a way whether there are independent members in the supervisory board; (c) way of payment of supervisory board member in a way whether payment is either fixed or variable.
Paper (Raheja, 2005) investigates interaction of insiders and outsiders in corporate board. This study analysis ideal size and structure of a corporate board. It is shown that the optimal board size and its structure is function of characteristics of directors and corporations.

\section{RESEARCH METHODOLOGY}

The goal of this paper is to analyses relationship between corporation financial performances and three above mentioned independent variables representing characteristics of a supervisory board.

Data for the research were collected by the survey conducted in 2010 and the data are for 2009. Survey included 18 independent variables and this research considers 3 above mentioned independent variables as characteristics of a supervisory boards. Data are statistically analyzed by formal test of hypothesis for difference between two population means. Null, $H_{0}$, and alternative hypothesis, $H_{1}$, are defined for each independent variable. Level of significance $\alpha$ or the probability of Type I Error (rejecting $H_{0}$ when it is true) used in this research is 0,05 . Data preparation includes elimination of all extreme values from data sets that are more than three standard deviations away from the mean, since they are considered as outliers. Although some authors (suggest A standard software package is used to make tests of hypothesis for the difference between two population means.

The first hypothesis test $\left(H T_{1}\right)$ is performed to determine whether the mean financial performance for corporations with more than three members in supervisory boards is greater than the mean financial performance for corporations with less or equal to three members in supervisory board. The formal hypothesis test is defined as follows:

where:

$$
\begin{aligned}
& H_{0}: \mu_{1} \leq \mu_{2} \\
& H_{1}: \mu_{1}>\mu_{2}
\end{aligned}
$$

$1=$ corporations with number of members of supervisory board $>3$ - variable 1 ,

$2=$ corporations with number members of supervisory board $\leq 3$ - variable 2 .

The results of $H T_{1}$ are given in table 1.

\begin{tabular}{|l|r|l|}
\hline & Variable 1 & Variable 2 \\
\hline Mean & 0,0108 & $-0,1231$ \\
\hline Variance & 0,0157 & 0,1018 \\
\hline Observations & 38 & 53 \\
\hline Hypothesized Mean Difference & 0 & \\
\hline df & 72 & \\
\hline t Stat & 2,7728 & \\
\hline $\mathrm{P}(\mathrm{T}<=\mathrm{t})$ one-tail & 0,0035 & \\
\hline t Critical one-tail & 1,6663 & \\
\hline $\mathrm{P}(\mathrm{T}<=\mathrm{t})$ two-tail & 0,0071 & \\
\hline t Critical two-tail & 1,9935 & \\
\hline
\end{tabular}

Tab. $1 . H T_{1}$ results 


\begin{tabular}{|l|r|r|}
\hline & Variable 1 & Variable 2 \\
\hline Mean & $-0,0973$ & $-0,0227$ \\
\hline Variance & 0,0799 & 0,0309 \\
\hline Observations & 63 & 30 \\
\hline Hypothesized Mean Difference & 0 & \\
\hline Df & 84 & \\
\hline t Stat & $-1,5580$ & \\
\hline $\mathrm{P}(\mathrm{T}<=\mathrm{t})$ one-tail & 0,0615 & \\
\hline $\mathrm{t}$ Critical one-tail & 1,6632 & \\
\hline $\mathrm{P}(\mathrm{T}<=\mathrm{t})$ two-tail & 0,1230 & \\
\hline t Critical two-tail & 1,9886 & \\
\hline
\end{tabular}

Tab. 2. $H T_{2}$ results

Because the observed $t$ value is greater than $t$ critical onetail value, the null hypothesis $H_{0}$ is rejected. Based on the results given in table 1 it can be concluded that there is statistical evidence that corporations with more than three members in supervisory boards have a larger mean financial performance than those with less or equal to three members.

The second hypothesis test $\left(H T_{2}\right)$ is performed to determine if a difference exists in mean financial performance for corporations without independent members in supervisory boards and corporations with independent members in supervisory boards. The hypothesis test is defined as follows:

where:

$$
\begin{gathered}
H_{0}: \mu_{1}=\mu_{2} \\
H_{1}: \mu_{1} \neq \mu_{2}
\end{gathered}
$$

$1=$ corporations without independent members of supervisory board - variable 1 ,

2 = corporations with independent members of supervisory board - variable 2.

The results of $H T_{2}$ are given in table 2. Because the observed t value is greater than $\mathrm{t}$ critical two-tail value, do not reject the null hypothesis $H_{0}$.

Based on the results given in table 2 it can be concluded that there is no statistical evidence that the mean financial performances differ between corporations without independent members and those with independent members in supervisory boards.

The third hypothesis test $\left(H T_{3}\right)$ is performed to determine if a difference exists in the mean financial performance for corporations with variable compensation of supervisory board members and corporations with fixed compensation of supervisory board members. The hypothesis test is defined as follows:

where:

$$
\begin{aligned}
& H_{0}: \mu_{1}=\mu_{2} \\
& H_{1}: \mu_{1} \neq \mu_{2}
\end{aligned}
$$

$1=$ corporations with variable compensation of supervisory board members - variable 1 ,

2 = companies with fixed compensation of supervisory board members - variable 2 .

The results of $H T_{3}$ are given in table 3 .

\begin{tabular}{|l|r|r|}
\hline & Variable 1 & Variable 2 \\
\hline Mean & $-0,0399$ & $-0,0667$ \\
\hline Variance & 0,0442 & 0,0492 \\
\hline Observations & 25 & 67 \\
\hline Hypothesized Mean Difference & 0 & \\
\hline df & 90 & \\
\hline $\mathrm{t}$ Stat & 0,5216 & \\
\hline $\mathrm{P}(\mathrm{T}<=\mathrm{t})$ one-tail & 0,3016 & \\
\hline $\mathrm{t}$ Critical one-tail & 1,6620 & \\
\hline $\mathrm{P}(\mathrm{T}<=\mathrm{t})$ two-tail & 0,6032 & \\
\hline $\mathrm{t}$ Critical two-tail & 1,9867 & \\
\hline
\end{tabular}

Tab. $3 . H T_{3}$ results
The decision rule for $\mathrm{HT}_{3}$ is as follows: if the observed $\mathrm{t}$ value is greater than $t$ critical two-tail value, reject the null hypothesis, otherwise, do not reject the null hypothesis. Because the observed $t$ value $<\mathrm{t}$ critical two-tail value, do not reject the null hypothesis $H_{0}$. Based on these sample data and results given in table 3 it can be concluded that there is no statistical evidence that the mean financial performances differ between corporations with variable compensation of supervisory board members and corporations with fixed compensation of supervisory board members

\section{CONCLUSION}

The results of the research, according to statistical hypothesis test for difference between two population means, show that there is significant difference in financial performances between corporations which supervisory board is composed up to three and more than three members. Corporations with supervisory board having more than three members are more successful than companies with less or equal to three supervisory board members. At the same time, this research shows that the structure of supervisory board in terms of having independent or dependent members does not significantly influence financial performances of companies. The same conclusion applies for relationship between type of payment of members of supervisory board and financial performances of companies in a way that the presence of variable payment of members of supervisory board does not influence financial performances of companies. Since the present research is limited to three variables, future research should include more influential variables as well as other ways of measuring financial performances such as Return on Assets (ROA) and Return on Equity (ROE). In the case of inclusion of more variables, multiple regression model will be also considered, as well as other mathematical analysis tools.

\section{REFERENCES}

Bonn, I. (2004). Board Structure and Firm Performance: Evidence from Australia. Journal of the Australian and New Zealand Academy of Management, Vol. 10, No. 1, (January 2004) pp. 14-24, ISSN 1833-3672

Brennan, N. (2006). Boards of Directors and Firm Performance: is there an expectations gap?, Corporate Governance: An International Review, Volume 14, Number 6, (November 2006) pp. 577-593, ISBN 0-41533910-3

Carcello, J. V., Hermanson, D. R., Neal, T. L. \& Riley, R. A. (2000). Board Characteristics and Audit Fees. Contemporary Accounting Research, Vol. 19, No. 3, (Fall 2002) pp. 365-384, ISSN 1191-3846

Carpenter, M. A. \& Westphal, J. D. (2001). The Strategic Context of External Networkties: Examining the Impact of Director Appointments on Board Involvement in Strategic Decision Making. Academy of Management, Vol. 44, No.4, (August 2001) pp. 639-660, ISSN: 1079-5545

Carter, D., Simkins, B., \& Simpson, W., (2002). Corporate Governance, Board Diversity, and Firm Value, The Financial Review, Vol. 38, 2003, (March 2002) pp. 33-53, ISSN 0732-8516

Coles, J. L., Daniel, N. D., \& Naveen, L. (2008). Boards: Does One Size Fit All?, Journal of Financial Economics, Vol. 87, No. 2, (February 2008) pp. 329-356, ISSN 0304-405X

Kaen, F. R. (2003). A Blueprint for Corporate Governance: Strategy, Accountability, and the Preservation of Shareholder Value, American Management Association, ISBN 0-8144-0586-X, New York

Raheja, C., (2005). Determinants of Board Size and Composition: A Theory of Corporate Boards, Journal of Financial and Quantitative Analysis, Vol. 40, No. 2, (June 2005) pp. 283-306, ISSN 0022-1090 